\title{
Effect of Seed Treatments and Storage Period on Seed Health Parameters of Pea (Pisum sativum L.) under Ambient Storage Conditions
}

\begin{abstract}
Background: Pea (Pisum sativum L.) is an important leguminous crop utilized as vegetable and pulse, being an important source of proteins. Pea seeds harbour various mycoflora both in field and during storage, which plays important role in reducing seed viability, germination and vigour inflicting considerable losses in yield and quality. There is scarcely any recommendation available to maintain seed quality during storage of pea seeds, hence present study was carried out.

Methods: Seeds of pea (cvs. Azad P. 1 and Arkel) were treated with Captan and Carbendazim 50\%WP fungicides @ $2.0 \mathrm{~g} / \mathrm{Kg}$ seed and stored under ambient conditions. The samples were drawn at three months interval to assess the effect of storage on seed quality parameters. The vigour index I, per cent germination and speed of germination of these seed samples were determined using ISTA rules. The detection of associated mycoflora in pea (Pisum sativum L.) seed samples was carried out by standard blotter method as recommended by International Seed Testing Association.

Result: Total fourteen fungal species were found associated with different pea seed samples. Out of these, maximum incidence of Alternaria alternata (21.36\%) followed by Aspergillus flavus (15.53\%), A. fumigatus (14.56\%), A. niger (11.60\%) and Rhizopus stolonifer $(9.71 \%)$, were recorded on untreated seed of pea cv. Azad P. 1, after 18 months of storage. The germination, speed of germination and vigour index of stored seed reduced with increase in storage period, whereas fungal incidence increased with the increasing storage period. Among the tested cultivars, germination in pea (cv. Arkel) remained above IMSCS even after 18 months of storage under ambient storage conditions. The maximum percent germination (99.0) was found in pea cv. Azad P. 1 seeds treated with Captan at 3 months of storage, whereas minimum percent germination (49.5) was found in untreated seed of pea cv. Azad P. 1 after 18 months of storage. The maximum speed of germination (23.88) was found in Captan treated seed of pea cv. Arkel at 0 month of storage and minimum speed of germination (3.52) was found in untreated seed of pea cv. Azad P. 1 at 18 months of storage. The maximum vigour index I (2339) was found in pea CV. Azad P. 1 (Captan treated seed) at 3 months of storage and minimum vigour index I (431) was found in untreated seed of pea cv. Azad P. 1 after 18 months of storage.
\end{abstract}

Key words: Mycoflora, Pea (Pisum sativum L.), Seed quality, Seedling vigour, Storage.

\section{INTRODUCTION}

Pea (Pisum sativum L.) belonging to family Leguminosae is an important legume crop widely cultivated throughout the world. Being a cool season crop, It is extensively grown in temperate zone but restricted to cooler altitudes in the tropics and winter season in subtropics. Pea is a dual-purpose crop, when its pods are harvested in green stage it is called as garden pea or green pea and when these pods are harvested after their maturity and are utilized as $d$ hal, these are called as field pea (Chandel and Kumar, 2017). Like green beans, cultivars of pea are not considered as pulses when they are used as vegetables and are classified into green peas and field pea or 'dry pea' (Calles, 2016). Pea contains enriched levels of amino acids, lysine and tryptophan. Pea is rich source of protein $(25 \%)$, sugars (8-12\%), amino acids, carbohydrates, vitamin $\mathrm{A}$ and $\mathrm{C}$, calcium and phosphorus besides having small quantity of iron. In addition, its cultivation is always beneficial to soil and our ecosystem due to its nitrogen fixing capabilities through which it contributes to the soil health and also helps to restrict the use of chemical fertilizers in subsequent crops (Stagnari et al., 2017).
ICAR-Indian Agricultural Research Institute, Regional Station, Karnal-132 001, Haryana, India.

'Department of Plant Pathology, College of Agriculture, Sardar Vallabhbhai Patel University of Agriculture and Technology, Meerut250 110, Uttar Pradesh, India.

Corresponding Author: Anuja Gupta, ICAR-Indian Agricultural Research Institute, Regional Station, Karnal-132 001, Haryana, India. Email: anujag2005@gmail.com

How to cite this article: Kumar, R., Gupta, A., Verma, K. and Singh, A. (2021). Effect of Seed Treatments and Storage Period on Seed Health Parameters of Pea (Pisum sativum L.) under Ambient Storage Conditions. Legume Research. DOI: 10.18805/ LR-4634.

Submitted: 10-04-2021 Accepted: 10-08-2021 Online:31-08-2021

Seed-borne or seed associated infections have been established to pose high adverse effect on the germination, growth and productivity of different crop plants and pea is not an exception (Kumar and Gupta, 2020). Pea besides its high susceptibility to pre-emergence damping off and to post- 
emergence root and foot rots, harbour various mycoflora both in fields and during storage, capable of causing considerable losses in yield and quality of pea (Jadon et al., 2020). Pea seeds loose its viability at faster rate during improper storage and exhibit poor field emergence and plant stand after sowing in next crop season. There is scarcely any recommendation available on storage of pea seeds. Keeping this in view, two popular garden pea cultivars viz., Azad P. 1 and Arkel was selected to study the effect of seed treatments and storage period on seed health parameters of pea (Pisum sativum L.).

\section{MATERIALS AND METHODS}

Seeds of two important cultivars of pea viz., Azad P. 1 and Arkel were treated with fungicides viz., Captan (2 g per $\mathrm{Kg}$ seed) and Carbendazim 50\% WP (2 g per $\mathrm{Kg}$ seed). Prior to these fungicidal seed treatments, the all seeds including fungicide untreated seed were treated with Deltamethrin insecticide to avoid insects' infestation especially bruchids (Callosobruchus spp.) infestation in the seeds stored under ambient condition. $4 \mathrm{ml}$ of Deltamethrin was prepared in $500 \mathrm{ml}$ of water and $5 \mathrm{ml}$ of this solution was used to mix in $1.0 \mathrm{Kg}$ of seed. The untreated seed (without fungicide) was used as control to assess the effect of these fungicides on seed during storage. The research was conducted during 2013-2015 at ICAR-Indian Agricultural Research Institute, Regional Station, Karnal. These seeds were stored under ambient conditions in cloth bags separately (one bag for each treatment for a variety) and seed quality parameters such as per cent germination, vigour index I, speed of germination and seed mycoflora were assessed at 3 months interval. Seeds were subjected to seed health testing using blotter technique. For percent seed germination $100 \times 4$ seeds were tested between layers of paper towel substrata at $25^{\circ} \mathrm{C}$ temperature by keeping in seed germinator as per ISTA (1999). For seedling vigour test, the vigour index I was determined using following formula (Abdul Baki and Anderson, 1973).
Seedling Vigour Index I =

Standard germination (\%) $\times$ Seedling length shoot + root length $(\mathrm{cm})\}$

For determining speed of germination, three layers of blotting paper presoaked in sterile distilled water were placed in each Petri dish. One hundred seeds were taken at random as per ISTA rules and 10 seeds per Petri dish were placed. Three replicates of each treatment were prepared. Each day numbers of germinated seeds were recorded and the speed of germination was calculated by using following formula:

Speed of germination $=N_{1} / 1+N_{2} / 2+\ldots .+N_{x} / x=N$

Where,

$N_{1}$ to $N_{x}$ are the no. of seed germinated on day 1 to day $x$; 1 to $X$ are the number of days.

\section{Detection of seed fungi using standard blotter method}

The seed mycoflora in pea seeds were detected by the standard blotter test as recommended by the International Seed Testing Association (ISTA, 1966). Triple layers of blotting paper presoaked in sterile distilled water were placed in each Petri dish. As per ISTA rules one hundred Seeds were selected randomly, of which 10 seeds per Petri dish were placed on triple layer of blotting paper (Fig 1). These Petri dishes were incubated at $27 \pm 2^{\circ} \mathrm{C}$ under diffused light for ten days. After 10 days of incubation, the plated seeds were examined under a stereoscopic binocular microscope for the associated fungi. The fungi which emerged on the seed surface were sub cultured on PDA for identification following the keys outlined by Gilman (1957), Booth (1971), Ellis (1971), Subramanian (1971) and Alexopoulos and Mims (1979).

\section{Statistical analysis}

All the data was analyzed statistically. The data on vigour index I, per cent germination and speed of germination was analyzed using Completely Randomized Design (CRD) with $\mathrm{P}=0.01$ level of significance.
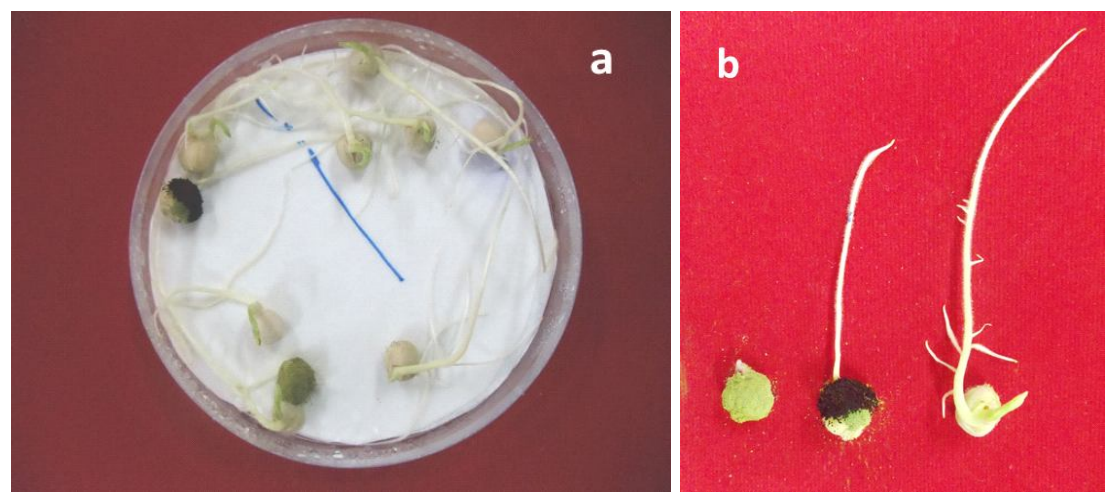

Fig 1: Detection of seed fungi on untreated pea seeds using standard blotter method (a), Incidence of mycoflora on untreated pea seeds under standard blotter method after 10 days of incubation (b). 


\section{RESULTS AND DISCUSSION Seed Germination}

Among the two cultivars of pea, higher seed germination $(90.2 \%)$ was found in pea cv. Azad P. 1 as compared to pea cv. Arkel (82.4\%) irrespective of storage period and seed treatments. Highest seed germination was recorded after 3 months of storage in both the cultivars, which got decreased with increase in the storage period, irrespective of seed treatments (Fig 2). The germination of untreated seed of pea cv. Azad P. 1 could be maintained above (>75\%) Indian minimum seed certification standard (IMSCS) up to 12 months only under ambient storage but fungicide treatment with Captan or Carbendazim could extend the germination above IMSCS upto 15 months, however in pea cV. Arkel, seed germination was maintained above IMSCS upto 18 months of ambient storage, irrespective of seed treatments, though higher seed germination was recorded in Captan $(84 \%)$ and Carbendazim (81\%) treated seed as against $75.75 \%$ in untreated seed at 18 months of ambient storage. The difference in per cent germination between the seed treatments with Captan and Carbendazim was statistically non-significant.

The per cent germination of seeds of the two cultivars of pea decreased considerably with the increase in storage period which may be potentially contributed to increased occurrence of fungal flora on stored seeds coupled with the loss in the content of carbohydrate, protein, amino acids etc., that induce increased moisture content, free fatty acid content and enhances other biochemical changes in the seed (Srivastava et al., 2013, 2014; Pedireddi et al., 2018). With the increase in period of seed storage, the seed germination decreased and the load of fungal flora increased. The increased storage period contributes to reduced germination in pea (Chandel and Kumar, 2017; Gupta and Kumar, 2020).

\section{Seedling vigour}

Seedling vigour of both cultivars of pea also followed a trend similar to seed germination. It was higher initially upto 6 months of storage and thereafter declined with the fall in seed germination in both the cultivars. Among the two cultivars of pea, higher seedling vigour (1789.48) was found in pea cv. Azad P. 1 as compared to Pea cv. Arkel (1705.67) irrespective of treatments (Table 1; Fig 3). However, as expected higher seedling vigour was observed in seeds treated with Captan or Carbendazim as against untreated seed in both the cultivars, irrespective of storage duration. The seedling vigour is challenged with the increase in storage of pea seeds, it gets decreased due to direct reduction in per cent germination and also due to increased incidence of seed mycoflora during storage which adversely

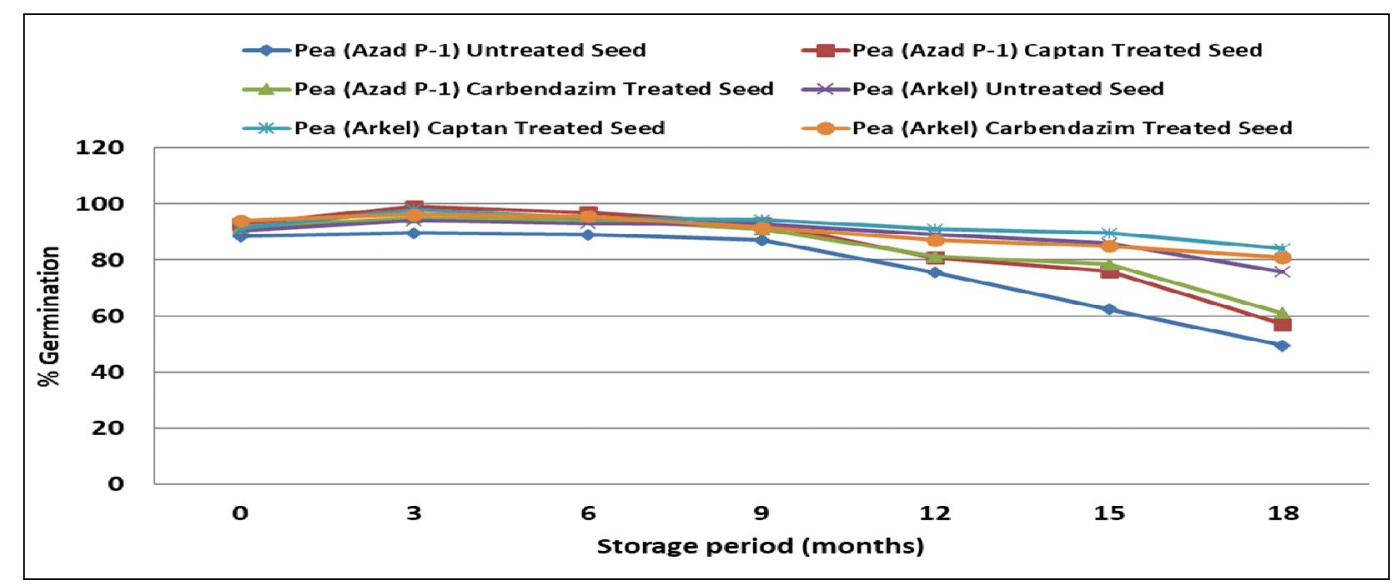

Fig 2: Effect of seed treatments and storage period on pea seed germination under ambient storage conditions.

Table 1: Effect of seed treatments and storage period on seedling vigour index I of pea cultivars under ambient conditions.

\begin{tabular}{|c|c|c|c|c|c|c|c|c|}
\hline \multirow{2}{*}{$\begin{array}{l}\text { Crop/ } \\
\text { Variety }\end{array}$} & \multirow{2}{*}{$\begin{array}{c}\text { Seed } \\
\text { treatment }\end{array}$} & \multicolumn{7}{|c|}{ Storage duration (months) } \\
\hline & & 0 & 3 & 6 & 9 & 12 & 15 & 18 \\
\hline \multirow[t]{3}{*}{ Pea (Azad P. 1) } & Untreated & $1540^{\mathrm{a}}$ & $1554^{a}$ & $1685^{a}$ & $1507^{a}$ & $1469^{a}$ & $821^{a}$ & $431^{\mathrm{a}}$ \\
\hline & Captan & $2329^{b}$ & $2339^{b}$ & $2307^{b}$ & $2178^{b}$ & $1733^{b}$ & $1380^{\mathrm{b}}$ & $905^{b}$ \\
\hline & Carbendazim & $2259^{c}$ & $2290^{b}$ & $2231^{c}$ & $2194^{b}$ & $1956^{c}$ & $1442^{c}$ & $1269^{c}$ \\
\hline \multirow[t]{3}{*}{ Pea (Arkel) } & Untreated & $1898^{d}$ & $1960^{c}$ & $1942^{d}$ & $1803^{c}$ & $1414^{\mathrm{a}}$ & $1198^{d}$ & $1092^{\mathrm{d}}$ \\
\hline & Captan & $2058^{e}$ & $2082^{d}$ & $2075^{e}$ & $1923^{d}$ & $1847^{d}$ & $1702^{\mathrm{e}}$ & $1533^{e}$ \\
\hline & Carbendazim & $2005^{e}$ & $2024^{d}$ & $2077^{e}$ & $1994^{e}$ & $1820^{d}$ & $1677^{e}$ & $1455^{f}$ \\
\hline CD (at $1.0 \%)$ & & 62.60 & 59.08 & 57.75 & 44.95 & 75.83 & 51.51 & 61.47 \\
\hline Sem \pm & & 17.75 & 16.75 & 16.37 & 12.74 & 21.49 & 14.60 & 17.43 \\
\hline
\end{tabular}

${ }^{*}$ The figures indicated with same letter in the same columns were not significantly different. 
affect the seedling growth parameters (Kumar et al. 2014; Chandel and Kumar, 2017; Wang et al. 2018).

\section{Speed of germination}

Among two cultivars of pea, the higher speed of germination was found in pea cv. Arkel (15.98) as against pea cv. Azad P. 1 (14.19) irrespective of treatments. The speed of germination also decreased in all the treatments with increase in the storage duration, however, seeds treated with Captan or Carbendazim maintained higher speed of germination than untreated seed at all storage periods (Fig. 4), but in maximum of the months' intervals of seed storage the differences between the speed of germination in both Captan and Carbendazim treated seeds were statistically nonsignificant. These results are in conformity with Pandita and Nagarajan (2002), who reported similar trend in garden pea (Pisum sativum). Garoma et al. (2017) also concluded that longer storage period had an adverse effect on germination speed in maize parental lines.

\section{Seed mycoflora}

In all, fourteen fungal species were found associated with pea seed samples of both varieties. These included
Alternaria alternata, Aspergillus flavus, A. fumigatus, A. niger, Chaetomium globosum, Cladosporium herbarum, Curvularia lunata, Colletotrichum sp., Drechslera sp., Fusarium oxysporum, Fusarium moniliforme, Penicillium sp., Macrophomina phaseolina and Rhizopus stolonifer. Out of these, five fungi i.e., Alternaria alternata, Aspergillus flavus, A. fumigatus, $A$. niger and Rhizopus stolonifer, were found in high frequencies. Initially the fungal incidence was low in both treated and untreated seeds and it increased with the increase in storage period. Maximum incidence of Alternaria alternata (21.36\%) followed by Aspergillus flavus (15.53\%), A. fumigatus (14.56\%), A. niger (11.60\%) and Rhizopus stolonifer $(9.71 \%)$, were recorded on untreated seed of pea cv. Azad P. 1 after 18 months of storage. The results obtained during the present study on occurrence of fungal species were in agreement with Ozgonen and Gulcu (2011), Singh et al. (2015), Dinler and Gunay (2018) and Pszczó3kowska et al. (2019) who reported similar fungal species on pea seeds. The maximum incidence of mycoflora associated with seed was found in untreated seed of pea cv. Azad P. 1 $(22.0 \%)$ followed by untreated seed of cv. Arkel (20.6\%) after 18 months of ambient storage. The fungal incidence in seeds

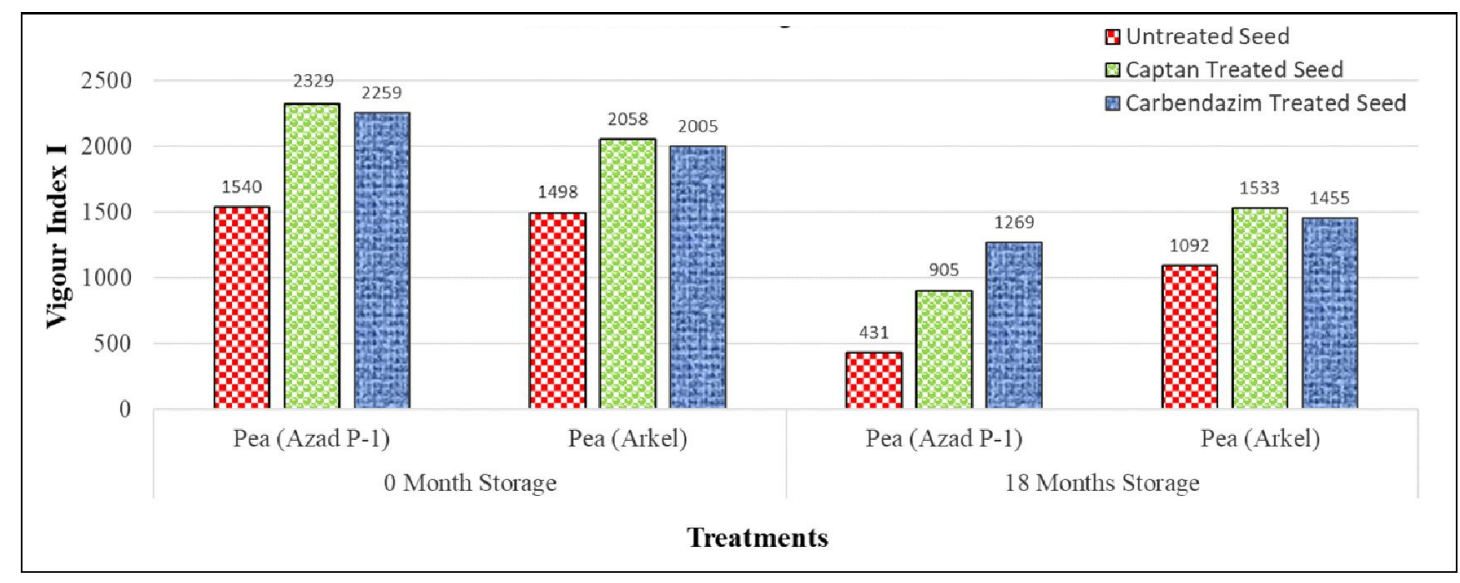

Fig 3: Effect of seed treatments and storage period on seedling vigour of pea seed under ambient storage conditions.

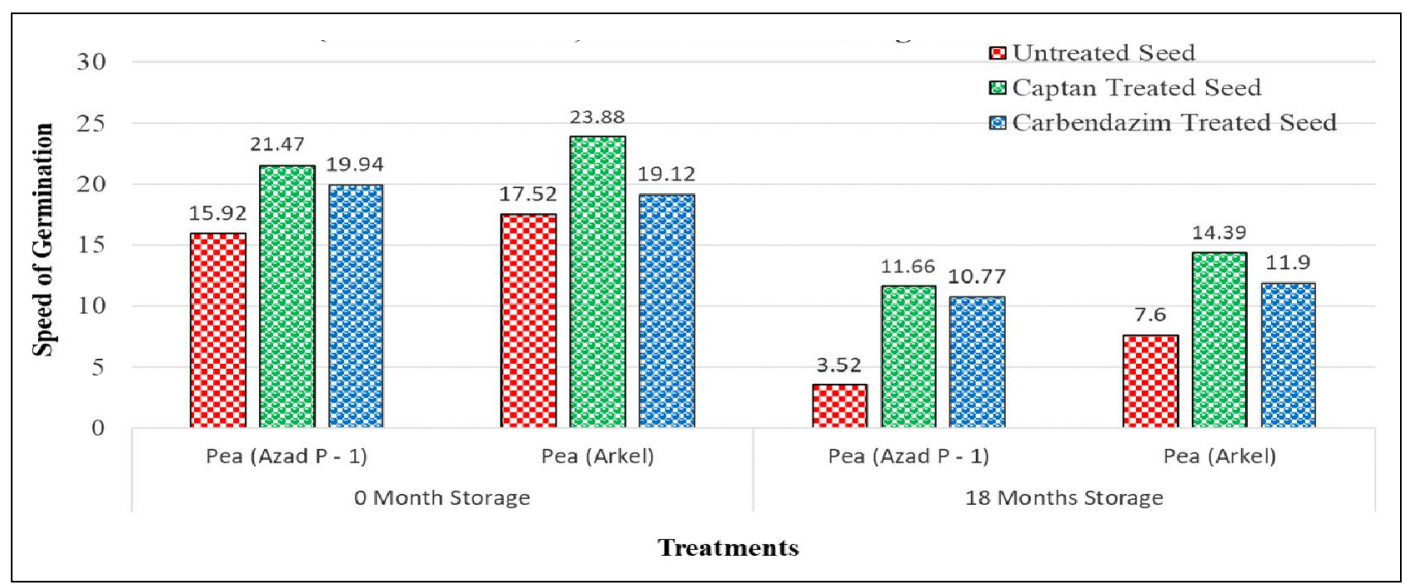

Fig 4: Effect of seed treatments and storage period on speed of germination in pea seed under ambient storage conditions. 


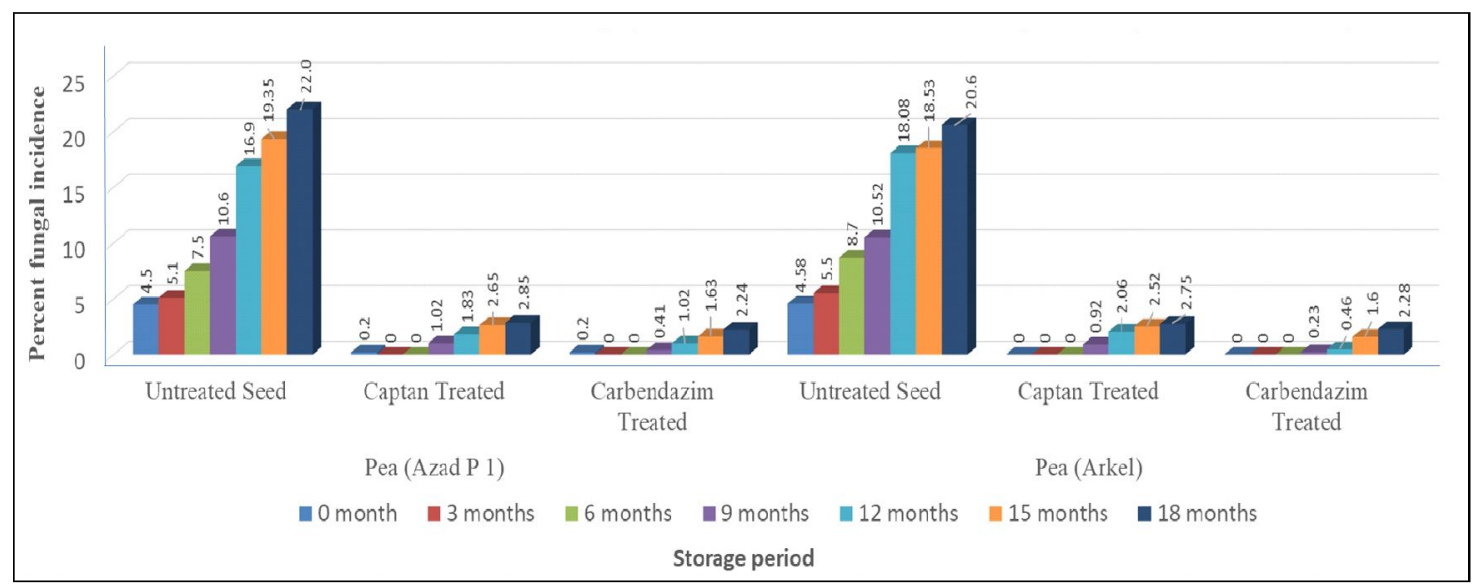

Fig 5: Effect of seed treatments and storage period on incidence of seed fungi on pea seeds under ambient storage conditions.

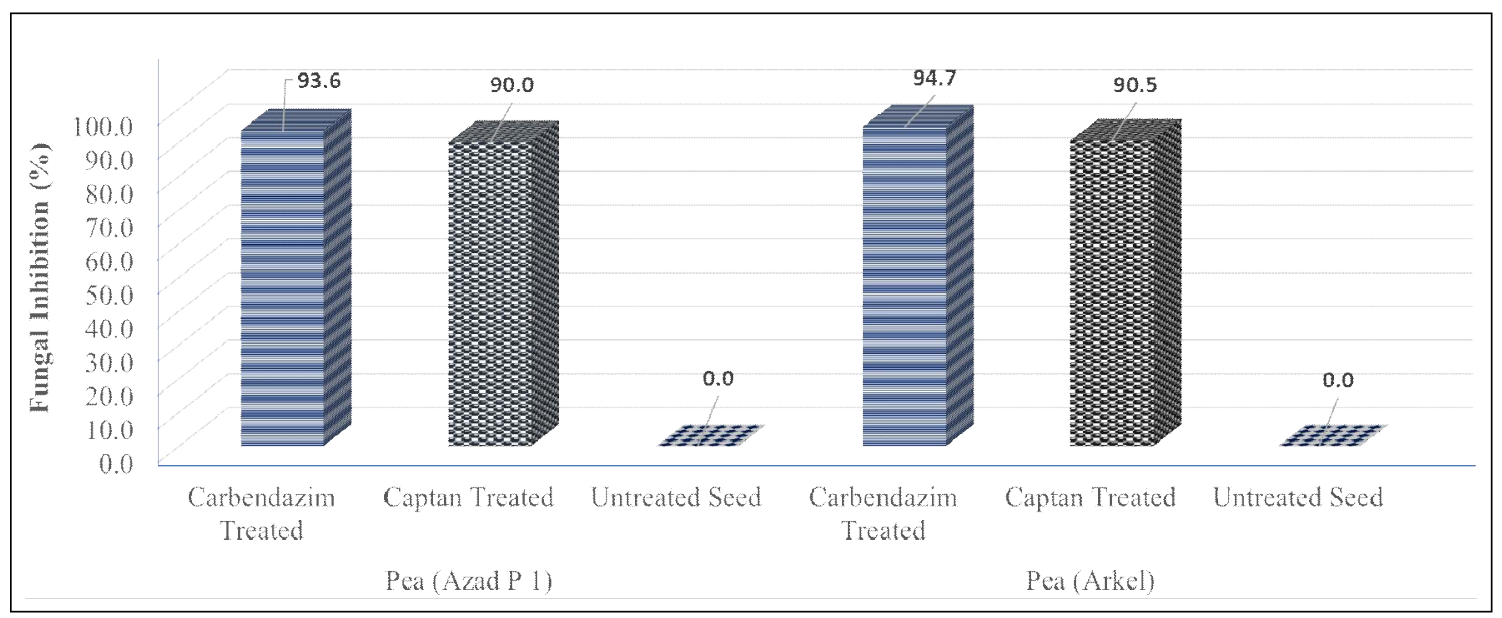

Fig 6: Efficacy of seed treatments against fungal load in pea (Pisum sativum L.) seeds.

treated with the fungicides was negligible during storage and remained restricted maximum upto $2.85 \%$ even after 18 months of ambient storage (Fig 5). Different cultivars of agricultural crops including pea respond differentially to the fungal seed infection and thereby may have different seed longevity under storage (Wilman et al., 2014; Pedireddi et al., 2018). The fungal species associated with seed play crucial role in determination of seed longevity particularly under ambient storage conditions, as these are the primary causative agents of seed biodeterioration which actually cause both quantitative and qualitative losses in seed morphology and seed viability (Srivastava et al., 2014; Singh et al., 2015; Kumar et al., 2020).

The overall efficacy of Carbendazim and Captan fungicides against seed fungi on both the cultivars was very good. Maximum fungal inhibition (94.70\%) was achieved with the seed treatment using Carbendazim $50 \%$ WP on pea seed (Arkel variety) followed by Carbendazim 50\% WP seed treatment of Azad P. 1 and Captan seed treatment of Arkel cultivar of pea resulting in $93.60 \%$ and $90.50 \%$ reduction in fungal occurrence on seed, respectively (Fig 6). These results were in conformity with Chaudhari et al. (2017), who managed the seed mycoflora of pigeonpea using seven fungicides and reported that Carbendazim 50\% and Carbendazim $12 \%$ in combination with mancozeb $63 \%$ were the most efficacious treatments in managing seed associated fungi and also for enhancing the seed quality parameters. Pan et al. (2010) also reported improvement in germination and seed viability of fungicides treated seeds of three crops viz., mungbean, mustard and rice. Lamichhane et al. (2020) concluded that the seed treatments not only provide the protection against seed-borne fungi but also helps to manage the soil-borne inoculum of certain phytopathogens in case of peas and chickpeas.

\section{CONCLUSION}

Pea (Pisum sativum L.) is an important dual-purpose crop being utilized as vegetable and pulse. The longevity of seed varied with respect to cultivar of pea. With increase in the storage period, there was decrease in seed germination, seedling vigour and speed of germination in seeds of both cultivars of pea, irrespective of seed treatment. The present study is helpful to understand the dynamics of seed associated fungal microorganisms under ambient storage 
conditions. Seed treatment with both fungicides viz., Captan and Carbendazim improved seed germination, speed of seed germination and seedling vigour in pea seeds and reduced seed mycoflora thereby maintained seed quality during storage; however the differences among the Captan and Carbendazim treated seeds for these seed health parameters were mostly statistically non-significant. Therefore, it can be concluded that seed treatment with any of these two fungicides, offers the better seed health and seed longevity in pea under ambient storage conditions.

\section{ACKNOWLEDGEMENT}

Authors are sincerely thankful to the Head, ICAR-IARI, Regional Station, Karnal-132 001 for providing necessary facilities to conduct the study.

\section{REFERENCES}

Abdul Baki, A.A. and Anderson, J.P. (1973). Vigour determination in soybean seed by multiple criteria. Crop Sciences. 13: 630-633.

Alexopoulos, C.J. and Mims, C.W. (1979). Introductory Mycology. $3^{\text {rd }}$ Edn. John Willey and Sons. Inc., U.S.A.

Booth, C. (1971). The genus Fusarium. Commonwealth Mycological Institute. Kew, Surrey, England.

Calles, T. (2016). The international year of pulses: what are they and why are they important? http://www.fao.org/pulses2016/resources/non-fao-resources/en/?keywords =Tropical \%20 Agriculture\%20Association. Accessed 01 March 2021, pp. 1-3.

Chandel, S. and Kumar, V. (2017). Effect of plant extracts as prestorage seed treatment on storage fungi, germination percentage and seedling vigour of pea (Pisum sativum). Indian Journal of Agricultural Sciences. 87(11): 1476-1481.

Chaudhari, A.K., Sharma, H., Jehani, M. and Sharma, J.K. (2017). Seed mycoflora associated with pigeonpea [Cajanus cajan (L.) Millsp.], their significance and the management. Journal of Pure and Applied Microbiology. 11(1): 567-575.

Dinler, H. and Gunay, M. (2018). Determination of fungal agents in some vegetables seeds in greenhouse production areas in Uşak Province. International Journal of Agriculture and Forestry. 8(2): 83-91. doi: 10.5923/j.jjaf.20180802.06.

Ellis, M.B. (1971). Dematiaceous Hyphomycetes. Commonwealth Mycological Institutes. Kew, Surrey, England.

Garoma, B., Chibsa, T., Keno, T. and Denbi, Y. (2017). Effect of storage period on seed germination of different maize parental lines. Journal of Natural Sciences Research. 7(4): 2017. ISSN 2225-0921 (Online).

Gillman, J.C. (1957). A manual of soil fungi. Lowa State Univ. Press.

Gupta, A. and Kumar, R. (2020). Management of seed-borne diseases: An integrated approach. In: [Kumar, R. and Gupta, A. (eds)]. Seed-borne Diseases of Agricultural Crops: Detection, Diagnosis and Management. Springer, Singapore. pp. 717-745. doi: https://doi.org/10.1007/978981-32-9046-4_25.

ISTA (1966). International Rules for Seed Testing. Proceedings of International Seed Testing Association. 31: 1-152.

ISTA (1999). International Rules for Seed testing. Seed Science and Technology. 24: 333.
Jadon, K.S., Thirumalaisamy, P.P. and Kumar, R. (2020). Major Seed-borne Diseases in Important pulses: Symptomatology, Aetiology and Economic Importance. In: Seed-borne Diseases of Agricultural Crops: Detection, diagnosis and management, [Kumar, R. and Gupta, A. (eds.)]. Springer, Singapore, pp. 469-542. doi: https://doi.org/10.1007/978981-32-9046-4_18.

Kumar, R. and Gupta, A. (eds) (2020). Seed-borne diseases of agricultural crops: Detection, diagnosis and management. Springer, Singapore, p. 871: doi: https://doi.org/10.1007/ 978-981-32-9046-4.

Kumar, R., Gupta, A., Maheshwari, V.K. and Atwal, S.S. (2014). Health status of farmers' saved seed of various paddy varieties in Haryana, India. Plant Pathology Journal. 13(3): 186192.

Kumar, R., Gupta, A., Srivastava, S., Devi, G., Singh, V.K., Goswami, S.K., Gurjar, M.S. and Aggarwal, R. (2020). Diagnosis and Detection of Seed-borne Fungal Phytopathogens. In: Seed-borne Diseases of Agricultural Crops: Detection, Diagnosis and Management. [Kumar, R. and Gupta, A. (eds)]. Springer, Singapore, pp. 107-142. https://doi.org/ 10.1007/978-981-32-9046-4_5.

Lamichhane, J.R., You, M.P., Laudinot, V., Barbetti, M.J. and Aubertot, J.N. (2020). Revisiting sustainability of fungicide seed treatments for field crops. Plant Disease. 104(3): https://doi.org/10.1094/PDIS-06-19-1157-FE.

Ozgonen, H. and Gulcu, M. (2011). Determination of mycoflora of pea (Pisum sativum) seeds and the effects of Rhizobium leguminosorum on fungal pathogens of peas. African Journal of Biotechnology. 10(33): 6235-6240. doi: 10.5897/ AJB10.2691.

Pan, S. Khalko, S. and Das, A. (2010). Effect of some fungicides on seed mycoflora, germination, viability and their persistence in treated seeds. The Journal of Plant Protection Sciences. 2(1): 59-64.

Pandita, V.K. and Nagarajan, S. (2002). Germination behaviour and field performance of garden pea (Pisum sativum) in relation to seed ageing. Indian Journal of Agricultural Sciences. 72(4): 213-215.

Pedireddi, U.R., Subba Rao, L.V., Choudhary, R., Patroti, P.D., Pallay, S., Kranthi, K.V.V.S., Kumar, A. and Deepak, N. (2018). Effect of seed infection on seed quality and longevity under storage of three rice varieties produced at different environments. Journal of Pharmacognosy and Phytochemistry. SP1: 3289-3298.

Pszczółkowska, A., Okorski, A., Fordoñski, G., Faligowska, A., Kaszkowiak, E., Olszewski, J. and Chareñska, A. (2019). The frequency of occurrence of pathogenic and saprotrophic fungi in pea seeds in different regions of Poland. Legume Research. 42(2): 270-276.

Singh, R.K., Mishra, P., Singh, R., Singh, G. and Kumar, H. (2015). Determination of mycoflora associated with pea (Pisum sativum) seeds. Annals of Biology. 31(1):101-103.

Srivastava, S., Srivastava, M., Kumar, R. and Sinha, A. (2013). Effect of seed-borne mycoflora on protein and amino acid content of Jatropha curcas L. seeds during storage. Vegetos-An International Journal of Plant Research. 26(2): 271-279. 
Srivastava, S., Srivastava, M., Kumar, R., Shrivastava, S.K., Gupta, G.N. and Sinha, A. (2014). Influence of fungi on carbohydrate and phenol content of Jatropha curcas seeds during storage. Journal of Pure and Applied Microbiology. 8(1): 761-766.

Stagnari, F., Maggio, A., Galieni, A. and Pisante, M. (2017). Multiple benefits of legumes for agriculture sustainability: an overview. Chemical and Biological Technologies in Agriculture. 4: 2 (2017): doi: 10.1186/s40538-016-0085-1.
Subramanian, C.V. (1971). Hypomycetes. Indian Council of Agricultural Research, New Delhi.

Wang, W., He, A., Peng, S., Huang, J., Cui, K. and Nie, L. (2018). The effect of storage condition and duration on the deterioration of primed rice seeds. Frontiers in Plant Science. 9: 172. doi: 10.3389/fpls.2018.00172.

Wilman, K., Stępieñ, L., Fabiańska, I. and Kachlicki, P. (2014). Plant-pathogenic fungi in seeds of different pea cultivars in Poland. Archives of Industrial Hygiene and Toxicology. 65: 329-338. doi: 10.2478/10004-1254-65-2014-2480. 